\title{
Gender, Land and Water in the Poverty Reduction Strategy and Country Assistance Strategy for Sri Lanka
}

\author{
I. VAN DER MOLEN
}

Ten years after the adoption of the Beijing Declaration, gender mainstreaming is still high on the donor agenda. Nonetheless, a number of evaluation reports clearly indicate that operationalisation of gender mainstreaming strategies remains a challenging task. The integration of gender concerns at the country level requires adequate financial and human resources, and strong institutions, which have been lacking in the recent past. Has the World Bank, as one of the largest financial institutions, learned from previous critique? This paper looks at Sri Lanka's poverty reduction strategy and the World Bank's country assistance strategy for Sri Lanka, with a focus on the agricultural sector.

Dix ans après l'adoption de la déclaration de Beijing, l'approche genre est toujours une priorité sur l'agenda des donateurs. Néanmoins, de nombreuses évaluations indiquent clairement que la mise en ouvre de stratégies incorporant l'approche genre reste difficile. L'intégration des questions de genre au niveau national nécessite des ressources humaines et financières adéquates et des institutions fortes, facteurs qui ont fait défaut ces dernières années. Etant l'une des principales institutions financières, la Banque mondiale a t-elle appris des critiques qui lui ont été faites? Cet article s'intéresse à la stratégie de réduction de la pauvreté au Sri Lanka et à la politique d'aide de la Banque mondiale à ce pays, l'accent étant mis sur le secteur agricole.

\section{INTRODUCTION}

In development assistance programmes of the early post-war period, 'gender awareness' was yet to emerge. Until the 1970s, women were not perceived as actors with their own agency, interests and knowledge, but primarily addressed as beneficiaries of social policies. An emphasis was placed upon women's reproductive roles and their practical needs, such as health care, nutrition and family planning. From the 1970s onwards, the way in which national governments conceptualised and

I. van der Molen is lecturer at the Department for Technology and Sustainable Development (T\&SD), University of Twente, The Netherlands and doing research in the area of governance and natural resource management.

The European Journal of Development Research, Vol.18, No.3, September 2006, pp.435-452 ISSN 0957-8811 print/ISSN 1743-9728 online

DOI: $10.1080 / 09578810600708197$ C 2006 European Association of Development Research and Training Institutes 
addressed women's positions evolved gradually from this welfare approach, to one that emphasised efficiency, equity and, in more recent times, empowerment (Moser, 1993). Notwithstanding considerable progress in the conceptualisation of gender, there was also critique. One of the most persistent critiques is that the operationalisation of these new approaches at country level has been erratic and inadequate. Against this backdrop, the question could be asked whether, and to what extent, donor organisations and international institutes have managed to overcome earlier criticisms on the inclusion of gender concerns in their assistance to developing countries.

To explore this question, the paper starts by providing an overview of the gender approaches of donor organisations between the 1970s and the 1990s, presented in more or less chronological order of their appearance. Because of the sheer quantity of documents produced by donor organisations on the subject, the remaining part of the paper focuses on one international institute only, in this case the World Bank, one of the leading financial institutes, which provides financial and technical assistance to countries to promote economic and social progress in developing countries. Accordingly, the overview of gender approaches by donor organisations between the 1970s and the 1990s is followed by a section describing the World Bank's gender approach, and some important changes at World Bank headquarters in response to earlier critique.

Subsequently, a more detailed review is provided about how gender concerns are incorporated in the World Bank's policies at country level in Sri Lanka. It does so by reviewing both the Poverty Reduction Strategy paper (PRS) of Sri Lanka and the World Bank Country Assistance Strategy for Sri Lanka with a thematic focus on the land and water sector. Although the PRS is produced by the Sri Lankan government in consultation with a multitude of other parties, the World Bank and other donor organisations, the document is conditional for receiving financial support from the World Bank, and therefore included in this analysis. Finally, we focus on the incorporation of gender in the second North-East Irrigated Agriculture Project (NEIAP) in Sri Lanka.

\section{OVERVIEW OF APPROACHES}

\section{From Welfare to 'Women in Development'}

As already indicated, in the post-war period, women were initially addressed as beneficiaries of social policies, while development projects and programmes paid particular attention to their reproductive roles and their practical needs such as health care, nutrition and family planning. However, in the 1970s there was increasing concern among academic researchers, feminists and staff of development organisations regarding the 'gender-blindness' in the design and implementation of development projects. Many of these projects simply overlooked or sidelined women, sometimes resulting in women's further subordination rather than women's equal participation (Geisler et al., 1999: 7; Chant and Gutman, 2000: 6). The need for a different approach was born, and translated into strategies which were generally labelled as the 'Women in Development' (WID) strategy.

This strategy not only called for improved education and employment opportunities, increased health and welfare services, but also for social justice (UNDP, 2003: 4). It took the view that women contributed actively, through their labour, to the formal and 
informal economy. Chant and Gutman (2000: 7) distinguish three common factors which stand out: (a) 'a focus on women as an "analytical and operational category"; (b) the setting-up of separate organizational structures for dealing with women; and (c) the development of women-specific policies and projects'.

\section{From 'Women in Development' To 'Gender and Development'}

It did not take long however for the first critical observations to be heard with respect to the WID approach. The organisations with a WID policy in place were accused of looking for ad hoc or add-on solutions, for treating symptoms rather than the integration of gender issues into mainstream policies, for creating separate women's units in their organisations, but without supplying these units with the necessary financial and human resources, expertise and placing these units at relatively 'harmless' locations within the organisational structure (Chant and Gutmann, 2000; Geisler et al., 1999). Some argued that the 'very act of separating women's programming from the central, mainstream programming which involved men, resulted in increased marginalization of women and their roles' (Anderson, 1990: 32). Furthermore, it was considered naive to assume that there is a single identifiable interest group called 'women' whose interests, position, voice and desires can be generalised (in time, place and across different groups) for the sake of development planning (Wieringa, 1998).

Increasing awareness of these shortcomings in the WID approach resulted in a shift to what was called the Gender and Development (GAD) approach. This approach, which started to gain importance in the early 1990s, addressed inequalities in social relationships, in power relationships, and in men's and women's social roles in relation to development. It emphasised that mainstream organisations are gendered in terms of their culture, rules and outcomes and that, therefore, the decisions, policies and resources from the mainstream are likely to neglect excluded or disadvantaged groups, including women, thereby reproducing gender inequalities and existing hierarchies (March et al., 1999: 9). Therefore, gender issues should be incorporated in the 'mainstream', and the term 'gender mainstreaming' was born, referring to the integration of gender concerns at all levels of decision making, policy formulation and implementation throughout all governmental institutions and policies. The Beijing Platform for Action, for example, emphasised that ' ...governments and other actors should promote an active and visible policy of mainstreaming a gender perspective in all policies and programmes so that, before decisions are taken, an analysis is made of the effects on women and men, respectively' (PfA, 1995, para. 202).

\section{POLICY PERSPECTIVES ON GENDER AND RESPONSE OF THE WORLD BANK}

\section{Policy Approach by the World Bank}

In its earlier years, the WID division within the World Bank recognised that an efficiency approach would be most effective to advocate the gender concerns within the World Bank. This has been referred to as 'WID entrepreneurship' (Razavi and Miller, 1995: 40 quoted in Geisler et al., 1999). Formally, at country level, the World Bank aims at a gender analysis within the WID approach, with gender-disaggregated analysis of 


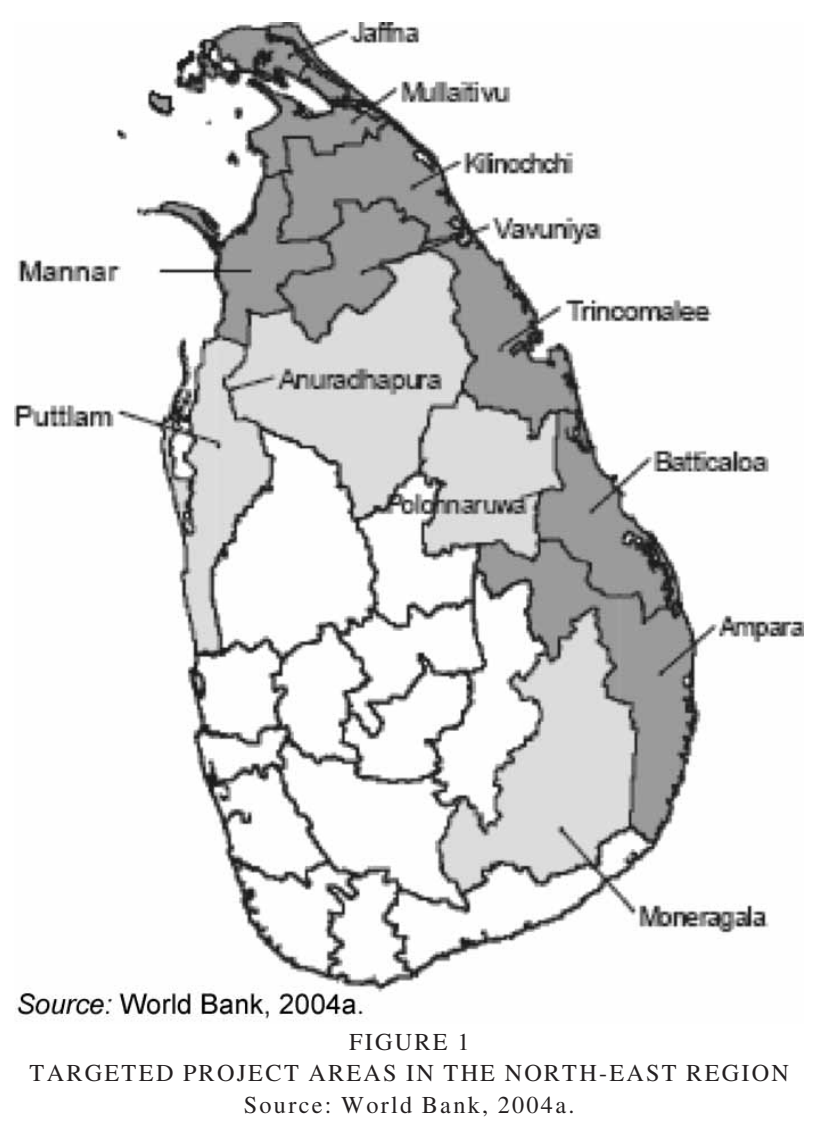

roles and access or control over resources. In reality, a gender-disaggregated analysis is not always visible in World Bank documents. For example, a recent World Bank report on poverty and rising regional inequality in Sri Lanka (Narayan and Yoshida; 2005), does not contain gender-disaggregated data; does not refer to gendered features of poverty and inequality, or to feminisation of poverty; fails to address gendered impacts of growth; and the word 'women' does not occur in the document.

The first studies on 'gender mainstreaming' in multilateral organisations showed that the actual operationalisation and implementation of mainstreaming gender has been extremely difficult and disappointing. Many initiatives faced a lack of the necessary skills, inadequate resources and weak institutions: 'The mechanisms established, from national women's machineries to "gender focal point system" in development institutions, face not just capacity but also resource and access constraints and tend to be marginalized' (UNDP, 2003: 7).

Furthermore, mainstreaming has proven difficult to achieve because of the compartmentalised way in which many national and international organisations are structured (UNDP, 2003). If gender is addressed as a cross-cutting issue while at the same time responsibility is not assumed by anyone in particular, and if there is 
a mandate for mainstreaming while there is no budget for hiring staff and experts, it is highly unlikely that mainstreaming will be achieved. This point resembles earlier criticism on the WID approach about creating women's units without supplying them with the necessary financial and human resources; or placing them in relatively 'harmless' (i.e. powerless) locations within the organisational structure (UNDP, 2003).

\section{Response of the World Bank to Earlier Critique}

In response to these critical reviews, and with the financial and technical assistance from several bilateral donor agencies, the World Bank took a number of initiatives to encourage mainstreaming by the organisation, for example, through the formulation of operational directives and the formulation of the policy paper 'Enhancing Women's Participation in Economic Development' in 1994 (Geisler et al., 1999). Moreover, several organisational changes were initiated, such the introduction of a new matrix system in 1997, aimed at improving country assistance strategies, with more flexible lending instruments, decentralisation of responsibilities and incentives to create more efficiency. Another important change was the shift of the central WID/gender unit to a more strategic position in the Network for Poverty Reduction and Economic Management (PREM). In an evaluation on gender mainstreaming within the World Bank by Geisler et al. (1999), the shift of the Gender Board under the PREM is referred to as a welcome, and necessary, change. With regard to regional gender units, the report is much less optimistic:

The situation of regional WID/gender units and gender focal points has, on the contrary, been erratic and variable. This is to a large degree due to the fact that internal accountability to gender mainstreaming is weak and the Bank's Regions enjoy a high degree of independence. Gender mainstreaming and the appointment of gender focal points in regional and country offices have been matters of personal choice of responsible senior management (Geisler et al., 1999, Executive Summary, p.8)

A similar conclusion can be found in other evaluation-reports, including those of the

World Bank itself. The operationalisation of gender mainstreaming at the level of Country Assistance Strategies, the key lending and programming documents at country level, and in individual projects and programs is considered to be relatively weak (eg Geisler et al., 1999; World Bank, 2001: 18). The Country Assistance Strategy cannot be seen in isolation from the Poverty Reduction Strategy. Therefore, before turning to the operationalisation of gender mainstreaming in the Country Assistance Strategy, the question should be asked how gender has been integrated in the Poverty Reduction Strategy for Sri Lanka.

\section{REGAINING SRI LANKA: THE POVERTY REDUCTION STRATEGY FOR} SRI LANKA

\section{Formulation of the Poverty Reduction Strategy}

'Regaining Sri Lanka: Vision and Strategy for Accelerated Development' was the ambitious title of Sri Lanka's policy document, Poverty Reduction Strategy (PRS) 
and Action Plan (Government of Sri Lanka (GOSL), December 2002). The PRS was formulated not only with input from ministries, experts, key stakeholders and NGO representatives, but also with input from the World Bank and other donor representatives, who had ample opportunity to contribute to the process.

The PRS of Sri Lanka defines four challenges, which are:

(i) increasing employment; creating two million new jobs and streamlining the public sector;

(ii) overcoming the public debt crisis;

(iii) investing in major reconstruction efforts; facilitation of reconciliation; meeting the basic needs of those affected by conflict, improving economic conditions; and

(iv) increasing income levels through higher productivity and investments, to reach a target of a 10 per cent economic growth rate.

The sections below concentrate on a few of the most relevant issues in the agricultural water sector. It argues that some socio-economic constraints are overlooked, and reveals why these constraints require more attention from a gender perspective.

\section{Occupational and Spatial Mobility}

Throughout the PRS of Sri Lanka, one can recognise an important assumption regarding the high level of spatial and occupational mobility among all population groups. The strategy as presented in 'Regaining Sri Lanka' involves a significant shift of employment from the overstaffed public sector to the private sector (which assumes occupational horizontal mobility); increased training, vocational training, education (which aims at vertical upward mobility); rural-urban migration (which requires spatial mobility and aims at horizontal or vertical upward occupational mobility); higher levels of entrepreneurship and settlement of industries in poor regions with secure, licensed access to water (industrial and commercial mobility), and a gradual shift from an economy based on low-productivity subsistence-oriented agriculture to higher-productivity services and industrialisation (occupational, spatial and industrial mobility).

Earlier research revealed, however, that - at present - the income-generating options for vulnerable households and women, in particular those in isolated communities, are limited due to limited spatial, economic and occupational mobility. The Country Gender Assessment of the Asian Development Bank (ADB) points out that the employment opportunities for women have strong gender features:

A major area of inequality, disadvantage, and gender discrimination is employment /.../ Women are concentrated in unpaid family labour in the agriculture sector, as plantation labour, in factory work in labour-intensive industries within and outside export processing zones, home-based economic activities in the peripheral market as subcontracted workers, in small-scale and often unviable self-employment in the informal sector and in overseas domestic service vulnerable to economic exploitation and sexual abuse. 
Hence, the majority of women has limited incomes and lack opportunities for upward occupational mobility (ADB, 2004: viii).

While the majority of women in isolated communities, in conflict-affected areas and in remote rural areas lack opportunities for upward occupational mobility, they also lack spatial mobility. Poorly maintained roads or heavily damaged roads result in long travel times between remote rural and urban areas, which affect both men and women. Many women in rural areas do not ride bicycles or mopeds, while women riding motorcycles or driving cars are exceptionally rare in rural areas. While transport is often arranged for agricultural day labour, for all other purposes women are still dependent on relatives, neighbours and their 'relations' who are travelling with horse-drawn carts, tractor-drawn carts, mopeds or motorbikes when buses are not available and rickshaws are too expensive (Molen, 2001a, 2001b; ADB, 2001).

\section{Shift from Low-productivity to High-productivity Agriculture}

In addition to gender features of spatial mobility, one can also observe a certain dependency in the cultivation of crops. There still is a strong gender-based division of labour in subsistence agriculture and the cultivation of cash crops: activities such as the preparation of land, slash and burn of land for chena cultivation; spraying of pesticides, weedicides and applying fertilisers, trashing, and participation in farmer organisations are all activities traditionally performed by men, even though some changes are taking place over time. This has only partially to do with men's advantage in terms of physical strength, but also with: (a) women's perceived lack of technical skills and subsequent exclusion from use of motorised equipment and subsequent training in the use of such equipment (eg tractors, trashing machines); (b) traditions and cultural beliefs which, for example, result in women's exclusion from the trashing floor; (c) their relative disadvantage compared to men in relation to land property; and (d) women's constraints with regard to spatial mobility (Molen, 2001a, 2001b).

How does this affect the gender impacts of the plans envisaged in the PRS of Sri Lanka? The GOSL intends to encourage smallholders to cultivate high-value horticulture crops, livestock, fisheries and fruit processing. When these activities can be performed close to their homes, in their home gardens or in the same village, or when regular and reliable transport is provided, this may have positive impacts on the income-earning opportunities of women in rural areas, even though the impacts are likely to be differentiated among different age groups or income groups. If, however, the intended shift from low-productivity subsistence agriculture to high-productivity agriculture involves the use of more technical equipment and cultivation in areas which are further located from peoples' homes, this will have major genderdifferentiated impacts on livelihood systems and productive activities.

\section{Removing Gender Discrimination from Legal Provisions}

The 'gradual shift from an economy based on low-productivity subsistence-oriented agriculture to higher-productivity services and industrialization' (GOSL, 2002: v) requires major changes in the area of land property such as the introduction of more private landownership, acceleration of freehold titling procedures, removal of all 
restrictions on the sale, lease transfer, subdivision and mortgage of land, and correction of gender-discrimination with regard to inheritance. The Jayabhoomi programme, for example, enables legalisation of encroached land, with short-term permits. There is a wide use of applications for Jayabhoomi grants, in particular for home gardens and ancestral paddy land. The gender-inequity is present in some of the legal provisions with regard to permanent leasehold under the Land Development Ordinance and under the Jayabhoomi programme. These provisions require the nomination of a successor. If no successor has been nominated, and the permit-holder dies without leaving behind a spouse, the priority is: sons, daughters, grandsons, granddaughters, father, mother, brothers, sisters, uncles, aunts, nephews, nieces (Land Development Ordinance, rule 1, 3rd schedule in: Legislative enactments of the Democratic Socialist Republic of Sri Lanka, revised edition, Vol. XI, 1980, 3rd Schedule; Agriculture and Lands Legislation, Vol. XI, Chapter 251-301: 434).

While this change is welcome, the correction of gender-discrimination with regard to inheritance will be a long process, and requires more than a correction of legal provisions. The fact that most land is still registered in the name of men is in the context of Sri Lanka to a large extent related to patrilocal marriage arrangements (diga marriages) whereby sons are more likely to inherit land from their parents than daughters (Benda-Beckmann et al., 1997; Molen, 2001a, 2001b).

\section{Including 'the Poor' In Water Resource Management}

'Regaining Sri Lanka' strongly emphasises improving the productivity of water resources, anticipating competition for water between agriculture, industry and urban uses. The introduction of transferable water entitlements involves:

the issuance of licenses for larger-scale water uses (bulk water entitlements) on each of the main watersheds and river basins. River basin committees, representing all stakeholders and with ample representation of the poor, will be established to issue the licenses/.../While small-scale water users are exempted from the licensing system, they will play a much more active role in allocating water entitlements and in planning the development and management of the water resources in their own river basins (GOSL, 2002: 67).

While the by-laws for farmer organisations in the north-east indeed refer specifically to women's membership of farmer organisations (World Bank, 2004c: 64 , art. 3.1.5), previous research has demonstrated that this does not yet guarantee that women feel free to voice their interests, concerns and preferences. As observed by Zwarteveen: 'Women's freedom to publicly interact with men is constrained by social practices and norms that define what sorts of interaction are permissible, with which men, in what contexts, and using defined modes of conduct. Discursive interactions within the domain of water users' organisations. . function informally to marginalize women and to prevent them from participating as peers' (Zwarteveen, 2000: 3).

\section{Reducing Vulnerability of Communities to Droughts, Floods and Famine}

Livelihood systems and productive activities are not only affected by shifts in policy as envisaged in Sri Lanka's PRS, but also by natural disasters and conflict. In isolated 
and poverty-stricken, and war-affected areas of Sri Lanka, the population has little or no resilience to disruption of their livelihoods by floods, droughts, soil erosion and/or coastal erosion. In anticipation of such emergencies, it is therefore particularly important to formulate gender-sensitive response, relief, recovery and mitigation measures related to such shocks.

In 'Regaining Sri Lanka' (predating the tsunami of December 2004), the GOSL expresses its concern for the vulnerability of isolated communities to droughts, floods and famine. It states: 'Isolation adds to vulnerability, since remote communities are both more susceptible to and likely to be impoverished by shocks, such as drought, floods and famine' (GOSL, 2002: 29). The gender features of this vulnerability, not mentioned in 'Regaining Sri Lanka', became painfully apparent when the tsunami of December 2004 took away a disproportionate number of lives among women and children (ADB, JBIC, WB, 2005: 10; Oxfam, 2005: 9-10).

\section{Gender-specific Vulnerabilities Among Female IDPs}

Before the tsunami took place in December 2004, 60 per cent of the Internally Displaced People (IDP) families were estimated to be female-headed. While 'Regaining Sri Lanka' does refer to female-headed households and women in conflict-affected areas, it does not elaborate on the particular constraints or specific vulnerabilities they face, nor does it refer to the capacity and strengths of these women in rebuilding their livelihoods, setting up new facilities in their communities after conflict or after floods, or their role in community development. Some of the specific risks and vulnerabilities among women who were displaced as result of the war in the north-east have been reported in a study by the Centre for Policy Alternatives:

Women face the loss of family members and male spouses, increased responsibility to provide for and protect children, threats to physical safety, including rape and sexual violence, psychological insecurity and more general issues of social marginalisation and lack of power. Land and property issues affecting women are intimately intertwined with women's human rights issues, living conditions, and questions regarding livelihood (Centre for Policy Alternatives, 2003: 45).

Several aid agencies (ADB/JBIC/WB, 2005; Oxfam, 2005) caution that tsunamiaffected women in Sri Lanka face similar risks to their physical security. The women in female-headed households in war-affected areas face particular constraints in terms of safety; they fear disappearances, child recruitment by the Liberation Tigers of Tamil Eelam (LTTE), potential harassment and sexual violence at checkpoints when travelling between their lands and welfare centres (Centre for Policy Alternatives, 2003: 47; personal notes, 2005). ${ }^{1}$

\section{Women's Involvement in Reconstruction}

These constraints and fears have an immediate impact on their spatial and occupational mobility. While the lack of infrastructure, schools and medical facilities, on the one hand, discouraged displaced women to return, on the other hand, it resulted in the involvement of women in setting up and managing new 
facilities, and an increase of women's self-employment in the non-traditional sphere (Centre for Policy Alternatives, 2003: 47). Similarly, soon after the tsunami, women, men and children from different ethnic and religious groups were actively involved in community-reconstruction in the south-east (field notes Ampara District, 2005). This shows both gender-specific constraints for displaced women and female headed households in war-affected or tsunami-affected areas, and reveals at the same time women's agency under extremely difficult situations.

Gender and Water Resource Management in the Action Plan Framework

The PRS 'Regaining Sri Lanka' is accompanied by an Action Plan in six areas: (a) macro policy framework; (b) employment, labour, human resource development; (c) financial services; (d) infrastructure development; (e) improving productivity; and (f) public sector reforms. Only the Action Plan Framework on Public Sector Reform formulates priority actions with regard to gender. Given the fact that the gender dimension is not mentioned in any of the other Action Plan Frameworks, one can conclude that the gender component is relatively compartmentalised. The Action Plan Framework for Public Sector Reform distinguishes five areas for future action (the objectives/strategies are in parenthesis):

- Reform structural policy to support pro-poor growth (public enterprise reform; private sector participation in infrastructure development; public-private partnerships);

- Create opportunities for pro-poor growth (connect poor regions to dynamic markets; revitalising rural development, raise productivity; improve water resource management);

- Investing in people (health care, social protection and community welfare, reduction air pollution; water supply and sanitation, Samurdhi welfare and poverty alleviation program, housing for the poor);

- Reforming governance and empowering the poor (community-driven development in the area of coastal preservation, fisheries, forestry, tourism and wildlife preservation; combat gender discrimination [italics added]; micro-credit facilities);

- Monitoring and evaluating progress in implementation of the PRS.

The objective to 'combat gender discrimination', under 'reforming governance and empowering the poor' consists of 14 priority actions. Only four of these may have an indirect impact on gender dimension in agricultural water resource management, if successfully implemented. These priority actions are: (a) an increase in the access of women to decision-making positions; (b) gender-sensitisation programs in government and large private companies; (c) to diversify vocational training opportunities for women; and (d) ensure women's equal access to agricultural extension programs. Although this does not have the features of a comprehensive program (yet), it is important to realise that its actual implementation is explicitly brought under the umbrella of the United Nations Development Program (UNDP), 
the International Labour Organization (ILO) and the Canadian International Development Agency (CIDA).

\section{Increasing Participation of Communities}

A promising trend is that the Action Plan Framework encourages communities to play an increasing role in natural resource management. The Action Plan Framework talks of consultation of stakeholders, community-based resource management in coastal preservation, enhanced participatory regulatory mechanisms in fisheries, formulation of legislation for greater community participation in fisheries and coastal conservation, participatory approaches to forestry management, and community-ranger partnerships. This assumes, rather optimistically, that women and men from vulnerable households have equal opportunities and capabilities to express their voice as wealthier households, while earlier case studies in Anuradhapura District showed that not only gender (see above) but also economic dependencies (credits, long-term indebtedness), social relations, economic relations (wage labour) and political pressure restrict the agency and opportunity of farmers to voice their opinion or to oppose measures through formal procedures.

\section{GENDER IN THE COUNTRY ASSISTANCE STRATEGY FOR SRI LANKA}

The Operations Evaluation Department of the World Bank revealed that many Country Assistance Strategies (CAS) are not adequately addressing issues which were identified by the more gender-aware Poverty Assessments. Out of 67 CAS which were reviewed by the World Bank Operations Evaluation Department, only 15 were rated as satisfactory in their incorporation of gender considerations. In Sri Lanka's CAS, gender was considered not relevant (World Bank, 2001: 18). Gender is not referred to in the PRS Core Areas and Priority CAS Outcomes (World Bank, 2003: 12). The CAS states:

While there is no freestanding program for gender activities proposed in this CAS, some operations do include a specific gender focus, such as the JSDFsupported program to encourage and expand women's rural financial institutions and networks. Rather, the approach is to ensure that in everything done by the Bank, the potential contribution of women is maximized in this country where women's roles are often discounted / . . / In summary, the CAS does not propose a gender program; but instead proposes a program that will ensure that women's contributions to development are realized, since it is clear in Sri Lanka that whenever this happens the overall impact is significantly greater (World Bank, 2003: 19).

The lack of integration of gender-dimensions in the CAS may be, to some extent, compensated by partnerships in implementation. ${ }^{2}$ The remainder of this paper will look at the integration of gender at the project level of a 'water-related' World Bank project in Sri Lanka: the Second North-East Irrigated Agricultural Project (NEIAP). 


\section{GENDER IN WORLD BANK PROJECTS IN SRI LANKA}

\section{The Second North-East Irrigated Agricultural Project (NEIAP)}

The Second NEIAP aims to provide assistance to conflict-affected communities in the North-East Province and adjoining areas to restore livelihoods, enhance agricultural and other production and incomes, and build capacity for sustainable, social and economic reintegration. The project aims to reach an estimated 24,000 families totalling about 100,000 people living in approximately 400 villages in the north-east region. The project has the following components (World Bank, 2004a: $6-7)$ :

1. Village rehabilitation and development for sustainable social and economic reintegration.

2. Essential rehabilitation and improvements to selected major/medium irrigation schemes.

3. Institutional capacity-building, project implementation support and project oversight.

The restoration and rehabilitation of irrigation tanks is an important component of this project. Many irrigation schemes in the north-east are damaged, and are therefore operating at much lower capacity or not at all. In addition, the NEIAP's Social Safeguards and Risk Assessment and Management Framework indicates that many rural roads that link villages, and farming and fishing communities to irrigation schemes, townships and market centres are heavily deteriorated, and that large areas of farm lands and previously inhabited areas are reported to have been heavily mined (World Bank, 2004c: 4).

The following sections will focus on the incorporation of the four priority actions as identified in the Action Plan Framework for Public Sector Reform:

- increase of access of women to decision-making positions;

- gender-sensitisation programmes in government and large private companies;

- diversify vocational training; encourage women's enrolment in technical training;

- ensure women's equal access to agricultural extension programs.

Spatial and Occupational Mobility, Vocational Training and Technical Skills

Under the 'livelihood assistance activities for vulnerable groups and people', the Project Information Document recognises the need for well-targeted assistance programmes to support the livelihoods of widowed and women-headed households, landmine victims, ex-combatants, people with war-induced deficient abilities in conflict-affected areas. It aims to support people who are likely to remain chronically poor because they cannot take advantage of the existing limited opportunities, who are trapped in pockets of poverty because they are geographically isolated, and who face constraints of mobility and integration 
in the short run (World Bank, 2004a: 3). As education is not one of the project's priorities, there is no mentioning of diversification and targeting of vocational technical training to women or women's groups to facilitate their participation in the choice or design of civil and mechanical works, nor of diversification and targeting of training to women to build knowledge, capacity and skills of women in the communities to move away from subsistence agriculture to high-productivity agriculture.

\section{Gender-sensitisation in National, Provincial and Local Government Agencies}

The NEIAP does not incorporate a component for gender-sensitisation of the de facto government agencies in conflict-affected areas of the north-east. One of the components of the Second NEIAP is the capacity-building of national, provincial and local government agencies. This incorporates primarily technical components such as

- the enhancement of equipment and facilities required to carry out the project activities;

- improvement and establishment of regional laboratories for testing construction materials, civil works construction, quality assurance and testing of agricultural soil;

- support for establishment of the groundwater monitoring network in the Jaffna district;

- short-term training and study tours to selected staff to improve implementation of the project and other long-term community-based reconstruction programs;

- provision of essential office equipment and facilities;

- and technical assistance for special studies and research.

\section{Gender-sensitive Response, Relief, Recovery and Reconstruction}

The policy with regard to relief, rehabilitation and reconstruction aims at bringing the population affected by the conflict back to productive life by providing basic amenities to help people to live with dignity, and to create a physically, economically and socially sustainable environment for their re-integration (World Bank, 2004b: 20).

The project foresees benefits such as increased household-level livelihood support and employment opportunities through small individual financial loans channelled to conflict-affected women in about 600 focal villages. Furthermore, it aims at capacity-building of communities through the formation and revitalisation of farmer organisations, rural development societies and women's rural development societies, and through training and agricultural support services.

The NEIAP recognises encroachment on private lands as a major social risk, which relates to the unauthorised occupation and use of lands belonging to displaced people consequent to the conflict. There is, however, no gendered analysis of such encroachment, of the livelihood constraints and strategies of affected men and 
women in conflict-affected areas, of the constraints for cultivation and selling products (eg safety concerns, or the impact of LTTE-imposed taxes on cultivation), or a gendered analysis of constraints for re-integration of returning IDPs. Similarly, there is no attention for gender-sensitive relief, recovery and reconstruction, other than through individual financial loans and the establishment of women's rural development societies.

\section{Ensure Women's Equal Access to Agricultural Extension Programs}

Although the report does not mention access to agricultural extension programs as such, the by-laws of farmer organisations to be established under the Second NEIAP incorporate the possibility of regular membership, associate membership and observers. The farmer organisations should ensure that persons from all sub-groups (women, agricultural labourers, and other marginalised social and cultural groups) obtain membership (art. 3.1.5), which is a positive step in the direction of more gender equity in membership of farmer organisations. Furthermore, not less than one-fifth of the total members of the Executive Committee are required to be women and the organisation should ensure that one of the office bearers should be a woman (art. 3.2.d) (World Bank, 2004c: 64).

\section{Encroachment of Land}

The issue of land encroachment, and potential for disputes related to encroachment, is considered by the project to be an important problem in the conflict-affected areas, even more than the possibility of involuntary disenfranchisement of private landowners through administrative procedures. The Social Safeguards and Risk Assessment and Management Framework (World Bank, 2004c) outlines the various scenarios and solutions for disputes related to encroachment of private land and government land, in the case of owners who were displaced or relocated, who died, who emigrated, who returned. Additionally, it outlines the scenarios in the case of tank bed cultivation, of lost documents, expired permits, inaccurate documentation and transfer of land. In the case of encroachment on private lands, owners retain their rights, and can negotiate with the user/occupier, appeal to the Agrarian Council, or file a case with the District Court. In case of encroachment of government lands, the permit holder can petition the Agrarian Council, appeal to the Divisional Secretary or file a case with the District Court.

The document assumes a functioning legal system, when it states:

In any case, Sri Lanka has a strong set of land laws and a functioning judicial system that would protect individuals' interests in land implementation modalities...Under these circumstances of a functioning administrative and legal system...prior owners would have administrative and judicial recourse to regain their previous lands (World Bank, 2004c: 9).

This is questionable, given the tense relations between different population groups and Tamil militant movements in the north and the east (McGilvray, 2001; Thangarajah, 2003; personal communication Ampara District, 2005). Even in nonconflict-affected areas, farmers rarely seek legal redress due to the difficult 
procedures in filing a court case, the time and cost involved, the administrative and geographical distance between the villages and district courts, and due to the chance of political interference before their case even reaches court (Molen, 2001a: 278).

A study on informal dispute resolution in the north-east revealed something similar. People from rural communities were reluctant to seek redress from judicial authorities, due to 'lack of transport and adequate roads, high cost of litigation, corruption, backlog of cases and lengthy procedures' (Centre for Policy Alternatives, est. 2003: 16). In the case of land disputes in rural areas, people seek support from the Grama Sevaka, the LTTE, the mosque committee, the police, or - eventually - the courts. Irrigation disputes are brought to the Grama Sevaka, the LTTE or the Water Agent (Centre for Policy Alternatives, est. 2003).

The NEIAP Social Safeguards and Risk Assessment and Management Framework does not recognise these constraints, nor does it refer to the potential additional constraints faced by women, for example, in terms of personal safety, fear for child recruitment, and legal ownership of property in case the woman's husband has disappeared or is missing (for more details, see Centre for Policy Studies, 2003a: 46).

\section{REFLECTION AND CONCLUSION}

The question which was asked at the start of this paper was: has the World Bank learned from previous lessons and criticisms with regard to the WID approach? Certainly, one can observe: (a) an increase of financial and human resources at the supranational level since the early 1970s (with financial and human resource support from Norway, the Netherlands, Canada, the Nordic group); (b) improvement of gender-analytical output at supranational level; and (c) improved strategic positioning of the gender division within the World Bank organisation.

However, even though the Netherlands Government supported a mission to Sri Lanka to strengthen the gender-dimensions of the PRS, this has not resulted in a comprehensive gender approach in the PRS or its Action Plans. Few intentions are indeed relevant and urgent from a gender perspective, such as the removal of the last remaining gender discrimination in legal provisions for land ownership; increased community participation in water resource management; and women's participation in farmer organisations.

Although these intentions can be labelled as positive developments, the general picture from the Poverty Reduction Strategy and its Action Plan Framework is one of weak analytical skills, a lack of gender-differentiated analysis, and weak programming. In the Action Plan Framework attached to the PRS of Sri Lanka, the GOSL does not formulate clear priority actions on gender in five out of six areas: (a) the macro policy framework; (b) employment, labour, human resource development; (c) financial services; (d) infrastructure development; and (e) improving productivity. Even in the Action Plan for Public Sector Reform, it fails to formulate gender priorities in a comprehensive way. The Poverty Reduction Strategy itself overlooks:

- socio-economic constraints in the area of spatial and occupational mobility;

- spatial dimensions which affect women's participation in 'new' economic sectors; 
- cultural constraints resulting in exclusion of women from the use of technology - and the training in the choice and use of technology required;

- social practices and norms and economic dependencies which define the mode of conduct and interaction, resulting in the marginalisation of women in meetings;

- safety concerns of female IDPs which prevent the spatial mobility of female IDPs and the mobility of women who stayed in former war-areas;

- women's role in reconstruction of their lives and in reconstruction of communities.

One important remark has to be made with regard to the conceptualisation of gender-dimension and 'women' in this paper. In the policy and project documents analysed for this study, the word 'gender' is in fact hardly ever used, and if so, it could be easily replaced by the word 'women' without differentiation in terms of class, caste, age, education levels, interests or needs. In the academic literature, a strong critique exists regarding such uncritical homogenisation of 'women' as a coherent group with identical interests and desires. There is a general consensus within the gender-literature that gender identity is shaped 'by a multiplicity of interacting time- and place continguent influences' (Chant and Gutmann, 2000: 9). The social and ideological construction of women as a homogenous group has proven not only to be incorrect, but such a construction automatically contributes to a polarisation of women's interests as opposed to men's interests, regardless of the history, context and issues at stake (Mohanty, 1997: 80).

As indicated by Mohanty, an even more serious concern is that, by presenting women from developing countries as one homogenous group based on the 'sameness' of oppression, they are often portrayed as 'ignorant, poor, uneducated, tradition-bound, domestic, family oriented, victimized' (Mohanty, 1997: 80). In the documents studied, women are frequently clustered together with internally displaced people, landless people, the elderly, children, indigenous people, landmine victims, people with war-induced deficient abilities and ex-combatants. 'Strong' women are non-existent in the discourse presented throughout the documents (both by the GOSL and the World Bank). The PRS, the Action Plan Framework, the Country Assistance Strategy and the NEIAP documents all demonstrate a surprising lack of knowledge of, or deliberate reluctance to look at, women's actual contribution, their capabilities, their skills and agency to facilitate change or reconstruct their lives, even under extremely difficult situations.

The discourse as found in these documents evolves around the vulnerable position of women as a separate group; it does not evolve around relationships of interdependence and autonomy within the household, within the community, or among women. Therefore, one can only agree with Kabeer, who argues: 'we need .to ground the conceptualization of empowerment in an understanding of the relationships of dependence, interdependence and autonomy which characterize gender relations in different cultures, the structures of risks, incentives and opportunities which they generate' (Kabeer, 2001: 80). 


\section{NOTES}

1. Although the situation has improved since the ceasefire agreement, disappearances, harassments, and child recruitment are still being reported in the north and the east.

2. The World Bank has partnerships with other multilateral and bilateral organisations in the implementation of the PRS, some of which have produced comprehensive gender assessments on country level. For example, in the priority area to 'create opportunities for pro-poor growth', the World Bank has a partnership with the ADB, EU, UN agencies, India, Japan, Netherlands, Sweden, Norway; in the area 'provide safe water/sewage/sanitation to all', there is a partnership with the ADB, UN, France, Germany, Japan and Norway. In the area of 'gender development', these partners are the $\mathrm{UN}$ agencies and Canada.

\section{REFERENCES}

ADB (Asian Development Bank), 2001, Perceptions of the Poor: the Participatory Poverty Assessmentz. s.l.

ADB, 2004, Country Gender Assessment Sri Lanka, South Asia Regional Department and Regional and Sustainable Development Department, Manila: Asian Development Bank.

ADB, JBIC (Japan Bank for International Cooperation), WB (World Bank), 2005, Post-Tsunami Recovery Program; Preliminary Damage and Needs Assessment, Jan. 10-28, Colombo.

Anderson, M.B., 1990, Women on the Agenda: UNIFEM's Experience in Mainstreaming with Women 1985-1990, New York: United Nations Development Fund for Women.

Appleton, B. and Smout, I. (eds), 2003, The Gender and Water Development Report 2003: Gender Perspectives on Policies in the Water Sector, Gender and Water Alliance, Leicestershire: WEDC (Water, Engineering and Development Centre). Available in hardcopy and at $<$ www.genderandwater.org $>$ (accessed 1 Dec. 2005).

Benda-Beckmann, K. von, Bruÿn, M. de, Dÿk, H. van, Hesseling, G., Koppen, B. van and Res, L. 1997, Rights of Women to the Natural Resources Land and Water, Women and Development, Working Paper 2, The Hague: Ministry of Foreign Affairs.

Centre for Policy Alternatives, undated, c. 2003a, Informal Dispute Resolution in the North East and Puttalam, Commissioned by UNHCR, Colombo: Centre for Policy Alternatives.

Centre for Policy Alternatives, 2003b, Land and Property Rights of Internally Displaced Persons, Colombo: Centre for Policy Alternatives.

Chant, S. and Gutmann, M., 2000, Mainstreaming Men into Gender and Development: Debates, reflections and experiences, Oxfam Working Papers, Oxford: Oxfam GB.

Ferree, M.M. and Hall, E.J., 1996, 'Rethinking Stratification from a Feminist Perspective: Gender, Race and Class in Mainstream Textbooks', American Sociological Review, Vol.61, No.6. (Dec 1996), pp.929-950.

Gamburd, M.R., 1998, ‘Absent Women and Their Extended Families: Sri Lanka's Migrant Housemaids', in C. Risseeuw and K. Ganesh (eds), Negotiation and Social Space; a Gendered Analysis of Changing Kin and Security Networks in South-Asia and Sub-Saharan Africa, London: Sage Publications, pp.276-291.

Geisler, G., Keller, B. and Norman, A.L. 1999, WID/Gender Units and the Experience of Gender Mainstreaming in Multilateral Organisation: Knights on White Horses?, a report submitted by the Christian Michelsen Institute to the Norwegian Ministry of Foreign Affairs, Oslo. Also available at $<$ http://odin.dep.no/ud/english/doc/reports/032001-990250/dok-bn.html > (accessed 12 Dec. 2005).

GOSL (Government of Sri Lanka), 2002, Regaining Sri Lanka: Vision and Strategy for Accelerated Development, December 2002. [Includes Part I: Vision for Growth; Part II: Connecting to Growth: Sri Lanka's Poverty Reduction Strategy; Part III Action Plan Matrices], Colombo.

Kabeer, N., 2001, 'Conflict Over Credit: Re-evaluating the Empowerment Potential of Loans to Women in Rural Bangladesh', World Development, Vol.29, No.1, pp.63-84.

March, C., Smyth, I. and Mulchopadhyay, M., 1999, A Guide to Gender Analysis Frameworks, Oxford: Oxfan.

McGilvray, D.B., 2001, Tamil and Muslim Identities in the East, in 'A History of Ethnic Conflict in Sri Lanka: Recollection, Reinterpretation \& Reconciliation', Marga Monograph Series on Ethnic Reconciliation No.24, Marga Institute, Sri Lanka.

Mohanty, C.T., 1997, 'Under Western Eyes: Feminist Scholarship and Colonial Discourses', in N. Visvanathan., L. Duggan, L. Nissonoff and N. Wiegersma, (eds), The Women, Gender and 
Development Reader, London and New Jersey: Zed Books; Dhaka: University Press, Bangkok: White Lotus; Halifax, Fernwood: Nova Scotia; Cape Town: David Philip, pp.79-86.

Molen, I. van der, 2001a, Rains, Droughts and Dreams of Prosperity: Resourceful Strategies in Irrigation Management and Beyond - the Sri Lankan Case, thesis, University of Twente, Enschede, The Netherlands.

Molen I. van der, 2001b, An Assessment of Female Participation in Minor Irrigation Systems of Sri Lanka, Working Paper 8, International Water Management Institute (IWMI), Colombo.

Moser, C., 1993, Gender Planning and Development: Theory, Practice and Training, London: Routledge.

Narayan, A. and Yoshida, N., 2005, Poverty in Sri Lanka: the Impact of Growth with Rising Inequality, World Bank, PREM Working Paper Series, South Asia Poverty Reduction and Economic Management (SASPR) report No. SASPR-8.

Novikova, I. and Molen I. van der, 2005, 'Mainstreaming Gender in the EU-Accession Process: the Case of the Baltic Republics', Journal of European Social Policies, Vol.15, No.2, pp.139-156, Sage Publications.

Oxfam, 2005, The Tsunami's Impact on Women, Oxfam Briefing Note, March 2005

PfA, 1995, Beijing Declaration and Platform for Action (PfA), adopted at the 4th World Conference on Women, Beijing, s.l.

Shahra, Razavi and Carol, Miller, 1995, Gender Mainstreaming; a Study of Efforts by the UNDP, the World Bank and the ILO to Institutionalize Gender Issues, United Nations Research Institute for Social Development, Geneva.

Thangarajah Y., 2003, 'Local Governance in the Eastern Province Kaluvanchikudy Pradeshiya Sabha \& Kattankudy Urban Council', in DSIUC/SAI. Local Governance and Conflict Management in Sri Lanka. Final Report, February 2003, by the Development Studies Institute of the University of Colombo (DSIUC) and the South Asia Institute (SAI) of the Heidelberg University in cooperation with the Sri Lanka Institute of Local Governance.

UNDP, 2003, Transforming the Mainstream; Gender in UNDP, available at <www.undp.org/ gender/docs/publication-transforming-the-mainstream.pdf $>$ (accessed 6 Dec. 2005).

Wieringa, S.E., 1998, 'Rethinking Gender Planning: A Critical Discussion of the Use of the Concept of Gender', Gender, Technology and Development, Vol. 2, No. 3, London: Sage Publications, pp.349-371.

World Bank, 2001, Integrating Gender in World Bank Assistance, Report No. 23035, 25 Oct. 2001, Operations Evaluation Department, Washington, DC: World Bank.

World Bank, 2003, Memorandum of the President of the International Development Association and the International Finance Corporation to the Executive Directors on a Country Assistance Strategy of the World Bank Group for the Democratic Socialist Republic of Sri Lanka, Report No. 25413-CE, Washington, DC: World Bank.

World Bank, 2004a, Project Information Document (PID), Appraisal Stage, Report No. AB502, prepared 7 April 2004; Washington, DC: World Bank.

World Bank, 2004b, Project Appraisal Document on a Proposed Credit in the Amount of SDR 44.6 Million (US\$ 64,7 Million equivalent) to the Democratic Socialist Republic of Sri Lanka for a Second North-East Irrigated Agriculture Project (new 11), Report 28542-LK, 25 May 2004, Rural Development Sector, South Asia Regional Office.

World Bank, 2004c, Social Safeguards \& Risk Assessment and Management Framework, Report 28629 prepared by Project Management Unit (NEIAP) North-East Provincial Council: Trincomalee.

World Bank, 2005, Sri Lanka Development Forum: The Economy, the Tsunami and Poverty Reduction, report prepared by R. Castro and P. Ventura, World Bank Poverty Reduction and Economic Management Sector Unit South Asia Region (SASPR). s.1.

M. Zwarteveen, 2000, Thinking About User Based Irrigation Organizations from a Feminist Perspective: Access, Participatory Parity and Democracy, Discussion note written for workshop 21: 'Human Actions and Natural Resources: Enough Water For All', Global Dialogue: the village in the 21st century - crops, jobs and livelihood, Hannover (unpublished). 